\title{
Comparison of Maternal, Perinatal, and Neonatal Outcomes of Asymptomatic and Symptomatic Pregnant Women with Coronavirus Disease-2019
}

\author{
Koronavirüs Hastalığı-2019 ile Enfekte Asemptomatik ve Semptomatik Gebe \\ Kadınların Maternal, Perinatal ve Neonatal Sonuçlarının Karşılaştırılması
}

\author{
(1) Tayfun VURAL1, (1) Burak BAYRAKTAR!, (1) Suna YILDIRIM KARACA1, (1) Ozan ODABAS1, (1) Nisel YILMAZ2, \\ (D) PInar SAMLIOGLU2, (1) Mehmet OZEREN3

\begin{abstract}
IUniversity of Health Sciences Turkey, Tepecik Training and Research Hospital, Clinic of Obstetrics and Gynecology, Izmir, Turkey 2University of Health Sciences Turkey, Tepecik Training and Research Hospital, Clinic of Clinical Microbiology, Izmir, Turkey 3University of Health Sciences Turkey, Tepecik Training and Research Hospital, Clinic of Perinatology, Izmir, Turkey
\end{abstract}

\begin{abstract}
Objective: This study aimed to compare the postpartum outcomes of asymptomatic and symptomatic patients with coronavirus disease-2019 (COVID-19).

Methods: This retrospective cohort study included pregnant women with COVID-19. Pregnant women were categorized into two sets as asymptomatic and symptomatic according to their clinics at the time of application. COVID-19 was diagnosed using the real-time reverse transcriptase-polymerase chain reaction on the oropharyngeal and nasopharyngeal swabs. Asymptomatic and symptomatic patients were compared in terms of maternal and perinatal outcomes.

Results: Our study population consisted of 20 asymptomatic and 41 symptomatic patients with laboratory-confirmed COVID-19. The rate of primary cesarean section was more than twice in the symptomatic group $(51.2 \%)$ than that of the asymptomatic group $(20 \%)(p=0.019)$. Both groups are quite similar in terms of maternal [respiratory support, COVID-19related treatment, and intensive care unit (ICU) admission], perinatal (preterm delivery, preterm premature rupture of membrane, preeclampsia, and mode of delivery), and neonatal outcomes [birth weight, Apgar scores, neonatal ICU (NICU) admission]. The rate of total cesarean section in the asymptomatic group (75\%) was statistically similar to the symptomatic group $(83 \%)(p=0.464)$. The NICU admission rate was found to be similar in the asymptomatic $(54.2 \%)$ and symptomatic groups $(50 \%)(p=0.858)$. However, NICU admissions were more frequent in the symptomatic group due to respiratory distress $(p=0.032)$. The breastfeeding rate is higher in the asymptomatic pregnant group as expected $(p=0.015)$. Additionally, the ferritin level was significantly lower in the asymptomatic group $(p=0.006)$. Conclusions: The rate of primary cesarean section is quite high in symptomatic patients with COVID-19. Additionally, the total cesarean section rate was extremely high in both groups. We expected more adverse outcomes in symptomatic patients; however, we found similar maternal, perinatal, and neonatal outcomes between both groups. Keywords: SARS-CoV-2, asymptomatic infection, coronavirus, COVID-19, pregnancy, vertical transmission
\end{abstract}

\begin{abstract}
öz
Amaç: Bu çalışmada, koronavirüs hastalığı-2019 (COVID-19) ile enfekte asemptomatik ve semptomatik gebelerin maternal, perinatal ve neonatal sonuçlarının karşılaştırılması amaçlanmıştır.

Yöntemler: Çalışmamız COVID-19 ile enfekte gebelerin değerlendirildiği retrospektif kohort çalışmasıdır. Gebeler hastaneye başvurularında asemptomatik ve semptomatik olarak iki gruba kategorize edildi. COVID-19 tanısı, orofaringeal ve nazofaringeal sürüntülerde gerçek zamanlı revers transkriptaz polimeraz zincir reaksiyonu ile konuldu. Asemptomatik ve semptomatik hastalar maternal ve perinatal sonuçlar açısından karşılaştırıldı.

Bulgular: Toplamda, laboratuvar tarafından tanısı doğrulanmış 20 asemptomatik ve 41 semptomatik gebe vardı. Primer sezaryen oran semptomatik grupta $(\% 51,2)$ asemptomatik grubun $(\% 20)$ iki katından fazlaydı $(p=0,019)$. Her iki grup maternal [solunum desteği, COVID-19 ile ilgili tedavi, yoğun bakım ünitesine (YBÜ) yatış], perinatal (preterm doğum, preterm prematür erken membran rüptürü, preeklampsi, doğum şekli) ve yenidoğan sonuçları [doğum ağırlığı, Apgar skorları, yenidoğan YBÜ'ye (YYBÜ) yatış] açısından oldukça benzerdi. Asemptomatik grupta total sezaryen oranı (\%75), semptomatik grupla (\%83) istatistiksel olarak benzerdi $(p=0,464)$. Asemptomatik grup $(\% 54,2)$ ve semptomatik grup $(\% 50)$ arasında YYBÜ'ye yatıs oranları benzer izlendi $(p=0,858)$. Ancak solunum sıkıntısı nedeniyle YYBÜ'ye yatış semptomatik grupta daha sık izlendi $(p=0,032)$. Emzirme oranı asemptomatik gebelerde beklendiği gibi daha yüksek izlendi $(p=0,015)$. Asemptomatik grupta ferritin düzeyi anlamlı olarak daha düşük izlendi $(p=0,006)$.

Sonuçlar: Bu çalışmada COVID-19 ile enfekte semptomatik gebelerde primer sezaryen oranının oldukça yüksek olduğu bulunmuştur. Ayrıca toplam sezaryen oranı her iki grupta da son derece yüksekti. Çalışmada semptomatik hastalarda daha olumsuz sonuçlar beklememize rağmen, her iki grup arasında benzer maternal, perinatal ve neonatal sonuçlar izledik. Anahtar kelimeler: SARS-CoV-2, asemptomatik enfeksiyon, koronavirüs, COVID-19, gebelik, vertikal geçiş
\end{abstract}

Address for Correspondence: B. Bayraktar, University of Health Sciences Turkey, Tepecik Training and Research Hospital, Clinic of Obstetrics and Gynecology, Izmir, Turkey

E-mail: drburakbayraktar@gmail.com ORCID ID: orcid.org/0000-0001-6233-4207
Received: 25 October 2021

Accepted: 09 January 2022

Online First: 24 January 2022

\section{Cite as: Vural T, Bayraktar B, Yildirim Karaca S, Odabas O, Yilmaz N, Samlioglu P, Ozeren M. Comparison of Maternal, Perinatal, and Neonatal Outcomes of} Asymptomatic and Symptomatic Pregnant Women with Coronavirus Disease-2019. Medeni Med J 2022;37:44-53

${ }^{\circledR}$ Copyright 2022 by the Istanbul Medeniyet University / Medeniyet Medical Journal published by Galenos Publishing House.

Licenced by Creative Commons Attribution-NonCommercial 4.0 International (CC BY-NC 4.0) 


\section{INTRODUCTION}

Coronavirus disease-2019 (COVID-19) is an infectious disease that is caused by severe acute respiratory syndrome coronavirus-2 (SARS-CoV-2), which can be transmitted to humans and cause a pandemic. The pandemic, which resulted in the death of many people globally, caused radical changes in health systems, socioeconomic life, and the psychology of individuals and the environment. These changes may continue for a long time after the pandemic'. Despite the efforts to rapidly implement the COVID-19 vaccine in many countries worldwide, including Turkey, the third wave of the pandemic occurred ${ }^{2-5}$.

New information about COVID-19 is being learned every day. COVID-19 is known as a respiratory tract infection with multi-organ involvement ${ }^{6}$ and its severity ranges from asymptomatic to fatal ${ }^{7}$. COVID-19- related knowledge in pregnancy and its impact on perinatal outcomes is limited ${ }^{8-10}$. Initially, SARS-CoV-2 was thought to cause mostly mild to moderate symptoms or rarely severe symptoms. However, subsequent studies showed asymptomatic cases, which are equally important in the spread of the disease. To date, fetal and early neonatal outcomes of asymptomatic women with COVID-19 remain controversial ${ }^{11-14}$.

Recently, seven different studies have shown a generally little or no difference in viral load between asymptomatic and symptomatic patients ${ }^{15-21}$. Additionally, asymptomatic groups tend to have a longer period of viral transmission than symptomatic groups ${ }^{22}$. Information about disease progression in pregnant women with asymptomatic COVID-19 is limited". Thus, understanding the clinical importance of asymptomatic pregnant women with positive SARS-CoV-2 may lead to favorable outcomes in their follow-up.

Considering that asymptomatic patients with SARSCoV-2 in Turkey may not seek medical care during their pregnancy, calculating the exact incidence of asymptomatic pregnant women would be difficult. Up to $14 \%$ of women who came for delivery were found to be positive for asymptomatic COVID-1911-13. Thus, this study aimed to investigate the postpartum outcomes of asymptomatic patients with SARS-CoV- 2 .

\section{MATERIALS and METHODS}

This retrospective cohort study evaluated pregnant women with COVID-19 diagnosis who were admitted to the University of Health Sciences Turkey, Tepecik Training and Research Hospital, Izmir, Turkey with obstetric complaints between March 30, 2020, and February 28, 2021.
The research was approved by the University of Health Sciences Turkey, Tepecik Training and Research Hospital Ethics Committee (decision no: 2021/03-39, date: 24.03.2021). Our study approval was obtained from the Turkish Ministry of Health (approval number: T19-04-31). The study complies with the 1964 Declaration of Helsinki. Written consent for data use was routinely obtained from all participants at admission.

This study is conducted in a tertiary pandemic hospital in Turkey. A separate delivery room, operating room, and service have been established for diagnosed or suspected cases of COVID-19. The personnel of these departments works in shifts with their personal protective equipment (PPE) only in their relevant departments. Some of the pregnant women with suspected COVID-19 were referred from surrounding hospitals, whereas others directly sought care at our hospital. Patients were quarantined in their isolated rooms. All participants were diagnosed with COVID-19 in our hospital, where all gave birth. No pregnant women were vaccinated during this study period.

COVID-19 was diagnosed using the real-time reverse transcriptase-polymerase chain reaction ( $r R T-P C R)$. The specimens were collected from the oropharyngeal and nasopharyngeal swabs. Swab samples were collected by trained personnel who wear appropriate PPE according to current guidelines. Swabs are transported to the microbiology laboratory in transfer tubes containing vNAT (viral nucleic acid buffer, Bio-speedy ${ }^{\circledR}$, Bioexen LTD, Turkey) for processing within a few hours. All samples were run in biosafety level-2 facilities with full PPE. Viral RNA was detected using the Bio-speedy ${ }^{\circledR}$ COVID-19 qPCR kit (Bioexen LTD). One positive and one negative control were added to each run to ensure an accurate result. A cycle threshold value of $<40$ was considered as a positive result, with $99.4 \%$ sensitivity and $99.0 \%$ specificity. The rRT-PCR test was also performed in all asymptomatic cases with a history of suspected contact or travel.

Symptomatic patients present with one or more signs or symptoms (rhinorrhea, sore throat, myalgia or fatigue, cough, shortness of breath, fever, nausea/ vomiting, headache, decreased taste, decreased odor, and diarrhea) at admission, whereas asymptomatic women have no signs or symptoms at presentation ${ }^{23}$. Follow-ups were conducted by phone for all pregnant women for 2 weeks postpartum to detect symptomatic infections. All neonates were tested for SARS-CoV-2 via rRT-PCR at $24 \mathrm{~h}$ of life. Neonatal events were recorded until 2 weeks postpartum. Comparisons were conducted on the two COVID-19 positive groups: one group with 
COVID-19-related symptoms $(n=41)$ and the other were asymptomatic $(n=20)$. All symptomatic patients had clinically mild diseases (cough, fever, flu-like symptoms, minimal dyspnea, and $\mathrm{O}_{2}$ saturation of $>95 \%$ on room air) in the whole course.

All clinical and laboratory findings of patients were obtained from the hospital computer system. The patients' blood tests and PCR tests were simultaneously studied. Maternal age, gravity, parity, comorbidity, delivery mode and indications, COVID-19-related symptoms, complete blood count, and biochemical values were evaluated. Lymphopenia refers to decreased peripheral blood lymphocytes, which generally corresponds to $<1,000$ lymphocytes/microL in adults. Disease progression to severe COVID-19, respiratory support, COVID-19 treatment, and intensive care unit (ICU) admission were considered maternal outcomes. Nasal cannula, face mask, or mechanical ventilation was utilized as respiratory supports. Hydroxychloroquine, azithromycin, or other antiviral drugs (e.g., remdesivir) were used to treat COVID-19. Perinatal outcomes included gestational age at delivery, mode of delivery, preterm premature rupture of membrane (PPROM), preeclampsia (PE), and fetal growth retardation. Birth weight, Apgar score, and neonatal ICU (NICU) admission were evaluated as neonatal outcomes.

\section{Definitions Used in This Study}

PE was defined as proteinuria or end-organ dysfunction along with new-onset hypertension after 20 weeks of gestation in a formerly normotensive woman ${ }^{24}$. Gestational hypertension is the absence of proteinuria or coexistence of end-organ damage with new-onset hypertension at $\geq 20^{\text {th }}$ week of pregnancy ${ }^{24}$. Gestational diabetes mellitus was diagnosed by comparing the two abnormal values on the $100 \mathrm{~g}$ oral glucose tolerance test in patients with abnormal results $(\geq 140 \mathrm{mg} / \mathrm{dL}$ ) on $50-\mathrm{g}$ oral glucose load. Preterm delivery is birth at $<37$ weeks of gestation. PPROM is a rupture of membranes at $<37$ weeks of gestation. Low birth weight (LBW) is $\leq 2,500 \mathrm{~g}$, whereas small for gestational age (SCA) is a birth weight below $10^{\text {th }}$ percentile according to gestational age. Fetal or intrauterine growth restriction (FGR/IUGR) is defined as an estimated fetal weight at $<10^{\text {th }}$ percentile. An increased fever was defined as a body temperature of $\geq 38^{\circ} \mathrm{C}$.

\section{Statistical Analysis}

The Statistical Package for the Social Sciences (SPSS) v26.0 (IBM ${ }^{\circledR}$ SPSS $^{\circledR}$ Statistics, New York, US) package program was used for the analysis and arrangement of tables ${ }^{25}$. Descriptive data were given as a number $(n)$, percentage mean and stand deviation [mean \pm standard deviation (SD)], and median [minimum (min) and maximum (max)]. The normality of the distributions was evaluated with the Shapiro-Wilk test and histogram graphs. The Student's t-test was used for the variables in which the parametric test conditions were met and data were presented as mean $\pm S D$. The Mann-Whitney $U$ test was used when the parametric test conditions were not met and the data were presented as median ( $\mathrm{min}$, max). Categorical variables were compared using the chisquare test. P-values of $<0.05$ were accepted as statistical significance.

\section{RESULTS}

This study compared 20 asymptomatic SARS-CoV2-positive pregnant women with 41 symptomatic SARSCoV-2-positive pregnant women. All participants were diagnosed with COVID-19 and were in the third trimester. Asymptomatic and symptomatic groups were mainly nulliparous ( $65 \%$ and $73.2 \%$, respectively; $p=0.511)$. The asymptomatic group was older than the symptomatic group $(p=0.042)$. The median gestational weeks at diagnosis was $34.4 \pm 6.9$ in asymptomatic pregnant women and $33.4 \pm 7.1$ in symptomatic women, with no statistical difference between them. No differences were found in maternal comorbidity or obstetric history between asymptomatic and symptomatic women. The time between COVID-19 diagnosis of and delivery was similar for both groups, as was the hospital stay duration (Table 1).

The most common symptoms in symptomatic pregnant women were fatigue $(78 \%)$, myalgia $(76 \%)$, sore throat (56\%), cough (54\%), and fever (41\%) (Table 2).

Asymptomatic and symptomatic pregnant women were compared in terms of maternal, perinatal, and neonatal outcomes. This study revealed a statistically similar total rate of cesarean section in the asymptomatic $(75 \%)$ and symptomatic group ( $83 \%)(p=0.464)$. However, the rate of primary cesarean section in symptomatic women $(51.2 \%)$ was more than twice the rate of the asymptomatic group ( $20 \%)(p=0.019)$. The rate of preterm birth was higher in asymptomatic women $(15 \%)$ than in symptomatic women (7.3\%); however, these differences were not statistically significant $(p=0.344)$. Similarly, the rate of LBW was higher in the asymptomatic pregnant participants $(14.3 \%)$ than those symptomatic $(2.4 \%)$ but differences were not statistically significant $(p=0.067)$. 
Table 1. Baseline characteristics of the study population with SARS-CoV-2 infection.

\begin{tabular}{|c|c|c|c|}
\hline & $\begin{array}{l}\text { Asymptomatic } \\
\text { group } n=20\end{array}$ & $\begin{array}{l}\text { Symptomatic group } \\
\text { (mild diseases) } n=41\end{array}$ & p-value \\
\hline Maternal age (year) (mean \pm SD) & $31 \pm 5.1$ & $27 \pm 4.7$ & 0.042 \\
\hline Gravity median (min, max) & $3(1-10)$ & $1(1-7)$ & 0.053 \\
\hline Parity (n, \%) & - & - & 0.511 \\
\hline Nulliparous & $13(65 \%)$ & $30(73.2 \%)$ & - \\
\hline Multiparous & $7(35 \%)$ & $11(26.8 \%)$ & - \\
\hline Multiple gestation prevalence (n, \%) & $1(5 \%)$ & $1(2.4 \%)$ & 0.598 \\
\hline PCR positive week of pregnancy (week) (mean \pm SD) & $34.4 \pm 6.9$ & $33.4 \pm 7.1$ & 0.614 \\
\hline Travel history (n, \%) & 0 & 0 & N/A \\
\hline \multicolumn{4}{|l|}{ Maternal comorbidity (n, \%) } \\
\hline Obesity (BMI of $\geq 30.0 \mathrm{~kg} / \mathrm{m}^{2}$ ) & $2(10 \%)$ & $1(2.4 \%)$ & 0.199 \\
\hline Asthma & 0 & $1(2.4 \%)$ & 0.481 \\
\hline Other chronic lung diseases & 0 & 0 & N/A \\
\hline Chronic cardiac diseases & 0 & $1(2.4 \%)$ & 0.481 \\
\hline Pregestational diabetes mellitus & 0 & $1(2.4 \%)$ & 0.481 \\
\hline Pregestational hypertension & 0 & 0 & N/A \\
\hline Thrombophilia & 0 & 0 & N/A \\
\hline Hypothyroidism & $1(5 \%)$ & $3(7.32 \%)$ & 0.731 \\
\hline Other thyroid diseases & 0 & 0 & N/A \\
\hline Smoking (n, \%) & 0 & 0 & N/A \\
\hline Assisted reproductive techniques (n, \%) & 0 & 0 & N/A \\
\hline \multicolumn{4}{|l|}{ Obstetric history (n, \%) } \\
\hline Previous gestational diabetes mellitus & $2(10 \%)$ & $1(2.4 \%)$ & 0.199 \\
\hline Previous gestational hypertension & 0 & 0 & N/A \\
\hline Previous preeclampsia & 0 & 0 & N/A \\
\hline Previous fetal growth retardation & $1(5 \%)$ & 0 & 0.148 \\
\hline Interval between COVID-19 positivity and birth (day) (mean \pm SD) & $28.6 \pm 46.1$ & $39.1 \pm 49$ & 0.425 \\
\hline Hospitalization duration (day) (mean \pm SD) & $2.8 \pm 1.1$ & $3.2 \pm 2$ & 0.385 \\
\hline Oxygen saturation (mean \pm SD) & $97.7 \pm 0.51$ & $97.2 \pm 0.53$ & 0.820 \\
\hline Systolic blood pressure $(\mathrm{mmHg})($ mean \pm SD) & $121 \pm 12$ & $118 \pm 15$ & 0.670 \\
\hline Diastolic blood pressure $(\mathrm{mmHg})($ mean $\pm \mathrm{SD})$ & $82 \pm 11$ & $84 \pm 12$ & 0.630 \\
\hline Fever $\left({ }^{\circ} \mathrm{C}\right)($ mean $\pm \mathrm{SD})$ & $36.4 \pm 0.26$ & $36.5 \pm 0.26$ & 0.960 \\
\hline Respiratory rate median (min-max) & $19(18-20)$ & $19(17-22)$ & 0.770 \\
\hline
\end{tabular}

\section{Table 2. Distribution of symptoms.}

\begin{tabular}{|l|l|l|}
\hline Symptomatic group (mild diseases) $\mathbf{n = 4 1}$ & $\mathbf{n}$ & $\%$ \\
\hline Fever of $\geq 38^{\circ} \mathrm{C}$ & 17 & $41 \%$ \\
\hline Cough & 22 & $54 \%$ \\
\hline Shortness of breath & 5 & $12 \%$ \\
\hline Fatigue & 32 & $78 \%$ \\
\hline Muscle or body aches & 31 & $76 \%$ \\
\hline New loss of smell & 9 & $22 \%$ \\
\hline New loss of taste & 8 & $20 \%$ \\
\hline Sore throat & 23 & $56 \%$ \\
\hline Chest pain & 1 & $2 \%$ \\
\hline Nausea and/or vomiting & 2 & $5 \%$ \\
\hline Diarrhea & 4 & $10 \%$ \\
\hline
\end{tabular}

Respiratory support was not required in either group except for one symptomatic patient. In this patient, only a nasal cannula was used as respiratory support. Intubation was not required in any of the patients in either the asymptomatic or symptomatic group (Table 3 ).

Perinatal and neonatal outcomes did not differ between the two groups. Both groups were statistically similar in terms of pregnancy complications, stillbirth, birth weight, Apgar score, and NICU admission. NICU admission rates were determined as $54.2 \%$ in the asymptomatic group and $50 \%$ in the symptomatic group (Table 3). 
Table 3. Maternal, perinatal, and neonatal outcomes of the study population.

\begin{tabular}{|c|c|c|c|}
\hline & $\begin{array}{l}\text { Asymptomatic group } \\
n=20\end{array}$ & $\begin{array}{l}\text { Symptomatic group } \\
\text { (mild diseases) } n=41\end{array}$ & p-value \\
\hline Gestational age at delivery (week) (mean \pm SD) & $38.4 \pm 1.4$ & $38.5 \pm 1.5$ & 0.724 \\
\hline Preterm delivery prevalence (<37 weeks) (n, \%) & $3(15 \%)$ & $3(7.3 \%)$ & 0.344 \\
\hline Threatened abortion (n, \%) & $3(15 \%)$ & $4(9.8 \%)$ & 0.546 \\
\hline PPROM (n, \%) & 0 & 0 & N/A \\
\hline Stillbirth* (n, \%) & $0^{a}$ & $0^{b}$ & N/A \\
\hline Fetal growth retardation* (n, \%) & $0^{a}$ & $0^{b}$ & N/A \\
\hline Fetal congenital anomaly* $(n, \%)$ & $0^{a}$ & $0^{\mathrm{b}}$ & N/A \\
\hline \multicolumn{4}{|l|}{ Pregnancy complications (n, \%) } \\
\hline Gestational hypertension & $1(5 \%)$ & $2(4.9 \%)$ & 0.983 \\
\hline Preeclampsia & 0 & $1(2.4 \%)$ & 0.481 \\
\hline Gestational diabetes & $2(10 \%)$ & $3(7.3 \%)$ & 0.719 \\
\hline Intrahepatic cholestasis of pregnancy & $1(5 \%)$ & $2(4.9 \%)$ & 0.983 \\
\hline \multicolumn{4}{|l|}{ Onset of labor (n, \%) } \\
\hline Elective cesarean section & $14(70 \%)$ & $29(70.7 \%)$ & 0.953 \\
\hline Spontaneous & $3(15 \%)$ & $5(12.2 \%)$ & 0.760 \\
\hline Induced & $3(15 \%)$ & 7 (17.1\%) & 0.837 \\
\hline Delivery type (n, \%) & & & 0.464 \\
\hline Vaginal delivery & $5(25 \%)$ & 7 (17.1\%) & \\
\hline Cesarean section & $15(75 \%)$ & $34(82.9 \%)$ & \\
\hline Primary C-section prevalence & $4(20 \%)$ & $21(51.2 \%)$ & 0.019 \\
\hline Gender* (n, \%) & a & b & 0.592 \\
\hline Male prevalence & $12(57.1 \%)$ & $21(50 \%)$ & \\
\hline Female prevalence & 9 (42.9\%) & $21(50 \%)$ & \\
\hline Birth weight* $(\mathrm{g})($ mean \pm SD) & $3150.3 \pm 518$ & $3268.5 \pm 470.4$ & 0.398 \\
\hline $\mathrm{LBW}^{*}(<2,500 \mathrm{~g})(\mathrm{n}, \%)$ & $3^{\text {a }}(14.3 \%)$ & $\mathrm{I}^{\mathrm{b}}(2.4 \%)$ & 0.067 \\
\hline Apgar score* $(n, \%)$ & a & b & \\
\hline$<7$ at $1^{\text {st }}$ minute & $2(9.5 \%)$ & 7 (16.7\%) & 0.445 \\
\hline$<7$ at $5^{\text {th }}$ minute & $1(4.8 \%)$ & $1(2.4 \%)$ & 0.611 \\
\hline NICU hospitalization* (n, \%) & $11^{\mathrm{a}}(52.4 \%)$ & $21^{\mathrm{b}}(50 \%)$ & 0.858 \\
\hline Cause of NICU admission ${ }^{*, c}(n, \%)$ & a & b & \\
\hline Prematurity & $1(4.8 \%)$ & $1(2.4 \%)$ & 0.611 \\
\hline Respiratory distress & $6(28.6 \%)$ & $14(33.3 \%)$ & 0.032 \\
\hline COVID-19 protocol & $10(47.7 \%)$ & $13(31 \%)$ & 0.250 \\
\hline Other & 0 & $1(2.4 \%)$ & 0.476 \\
\hline Days in NICU* (mean \pm SD) & $2.4 \pm 1.4$ & $2.8 \pm 1.5$ & 0.424 \\
\hline Perinatal mortality* $(n, \%)$ & $0^{a}$ & $0^{\mathrm{b}}$ & N/A \\
\hline Maternal mortality (n, \%) & 0 & 0 & N/A \\
\hline Maternal breastfeeding (n, \%) & $20(100 \%)$ & $31(75.6 \%)$ & 0.015 \\
\hline Neonatal PCR positivity* (n, \%) & $\mathrm{j}^{\mathrm{a}}(4.8 \%)$ & $0^{\mathrm{b}}$ & 0.154 \\
\hline Maternal intensive care unit admission (n, \%) & 0 & 0 & N/A \\
\hline
\end{tabular}




\begin{tabular}{|c|c|c|c|}
\hline & $\begin{array}{l}\text { Asymptomatic group } \\
\mathrm{n}=20\end{array}$ & $\begin{array}{l}\text { Symptomatic group (mild } \\
\text { diseases) } n=41\end{array}$ & p-value \\
\hline \multicolumn{4}{|l|}{ Respiratory support (n, \%) } \\
\hline Nasal cannula & 0 & $1(2.4 \%)$ & 0.481 \\
\hline Breathing mask & 0 & 0 & N/A \\
\hline Intubation & 0 & 0 & N/A \\
\hline \multicolumn{4}{|l|}{ COVID-19 treatment (n, \%) } \\
\hline Hydroxychloroquine & 0 & $1(2.4 \%)$ & 0.481 \\
\hline Azithromycin & 0 & 0 & N/A \\
\hline Remdesivir/other antivirals & $1(5 \%)$ & $1(2.4 \%)$ & 0.598 \\
\hline Low molecular weight heparin & $4(20 \%)$ & $10(24.4 \%)$ & 0.701 \\
\hline Bronchodilator & 0 & $1(2.4 \%)$ & 0.481 \\
\hline
\end{tabular}

No difference was detected in the COVID-19 treatment between the two groups. Hydroxychloroquine, azithromycin, or antiviral agents were not used by either group except for one symptomatic case, in which hydroxychloroquine was administered. Low molecular weight heparin was used in up to a quarter of cases in both groups. No ICU admissions were recorded from either group, as well as maternal deaths. The breastfeeding rate was higher in asymptomatic pregnant women as expected $(p=0.015)$. Additionally, NICU admissions were more frequent in the symptomatic group due to respiratory distress $(p=0.032)$. Within the first $24 \mathrm{~h}$ of life, 63 infants were tested with a nasopharyngeal swab, which revealed a positive COVID-19 test in only 1 newborn (from the asymptomatic group). All others were negative for COVID-19 (Table 3).

The laboratory findings for both the asymptomatic and symptomatic groups are compared in Table 4. Ferritin was significantly lower in the asymptomatic group $(p=0.006)$. No significant differences were found between the groups in point of C-reactive protein (CRP) levels, lymphocyte counts, lymphopenia rates, platelet counts, D-dimer levels, and aspartate transaminase (AST)/alanine aminotransferase (ALT) ratios.

\section{DISCUSSION}

The principal study results revealed that the rate of primary cesarean section in the symptomatic group is twice more than that of the asymptomatic group. A second finding was that both groups were quite similar in terms of maternal, perinatal, and neonatal outcomes. Third, the total rates of cesarean section and preterm delivery were not statistically different in both groups.
Fourth, the symptoms of asymptomatic patients did not progress, and they remained asymptomatic. Fifth, the clinical course and laboratory values of the asymptomatic and symptomatic groups were quite similar. And finally, the third trimester seemed to be the most vulnerable period to infection.

This study revealed that cesarean section rates were similar between the asymptomatic and symptomatic women. Similarly, London et al." revealed that cesarean section rates were not statistically different in both groups, although its rate in symptomatic patients (45.8\%) was higher than that of asymptomatic patients (27.3\%). Jenabi et al. ${ }^{26}$ revealed that the rate of cesarean section in symptomatic patients was more than four times higher than in asymptomatic patients. However, the present study revealed that the rate of primary cesarean section was more than two times higher in symptomatic women (51.2\%) than in asymptomatic women (20\%). A systematic review by Turan et al. ${ }^{27}$ reported that the total cesarean rate was $84.1 \%$ and the vaginal delivery rate was $15.9 \%$ in patients with COVID-19. Other articles revealed that the cesarean section rate in patients with SARS-CoV-2 was $58.5 \%$, $65 \%, 66.4 \%, 71.2 \%$, and $92 \%$, respectively ${ }^{28-32}$. Consistent with the literature, the rate of cesarean section in the present study was $80.3 \%$ with a $19.7 \%$ rate of vaginal delivery. Extremely high cesarean rates in patients with COVID-19 may be mainly due to concerns about perinatal transmission or contagion to healthcare workers as well as obstetric indications. Additionally, Turan et al. ${ }^{27}$ reported that this high cesarean section rate may be iatrogenic. 


\begin{tabular}{|c|c|c|c|}
\hline & Asymptomatic group $n=20$ & Symptomatic group $n=41$ & p-value \\
\hline $\begin{array}{l}\text { Lymphocyte }\left({ }^{*} 10^{3} / \mathrm{mm}^{3}\right)(\text { mean } \pm \text { SD) } \\
(\min -\max )\end{array}$ & $1,524 \pm 689(500-2,600)$ & $1,508 \pm 699(500-3,400)$ & 0.938 \\
\hline Lymphopenia <1000 (*103/mm³) (n, \%) & $4(20 \%)$ & $7(17.1 \%)$ & 0.780 \\
\hline AST (U/L) (mean \pm SD) (min-max) & $18.93 \pm 9.56(9-46)$ & $19.36 \pm 8.91(10-48)$ & 0.713 \\
\hline ALT (U/L) (mean \pm SD) (min-max) & $16.94 \pm 10.66(5-60)$ & $17.17 \pm 11.43(7-49)$ & 0.680 \\
\hline $\mathrm{AST} / \mathrm{ALT}$ ratio (mean $\pm \mathrm{SD})$ & $1.28 \pm 0.49$ & $1.32 \pm 0.61$ & 0.813 \\
\hline Platelet $\left({ }^{*} 10^{3} / \mathrm{mm}^{3}\right)($ mean \pm SD) $(\min -\max )$ & $\begin{array}{l}217,000 \pm 98,944 \\
(99,000-370,000) \\
\end{array}$ & $\begin{array}{l}216,000 \pm 64,677 \\
(114,000-380,000) \\
\end{array}$ & 0.965 \\
\hline $\mathrm{CRP}(\mathrm{mg} / \mathrm{L})(\mathrm{mean} \pm \mathrm{SD})(\min -\max )$ & $7.46 \pm 4.89(1-60)$ & $13.25 \pm 17.12(1-100)$ & 0.299 \\
\hline Ferritin $(\mathrm{ng} / \mathrm{mL})($ mean $\pm \mathrm{SD})(\min -\max )$ & $17.53 \pm 10.26(1-85)$ & $34.94 \pm 26.22(6-115)$ & 0.006 \\
\hline D-dimer (ug/L) (mean \pm SD) (min-max) & $2862.7 \pm 2510.2(454-10,670)$ & $2484.4 \pm 2470.7(220-12,790)$ & 0.620 \\
\hline
\end{tabular}

Follow-ups were conducted for all patients in the study by phone for 2 weeks postpartum to detect symptomatic infections. None of the asymptomatic patients developed symptoms. Similarly, the literature reported that most asymptomatic patients remain asymptomatic ${ }^{11,12,14,28}$. This result is likely related to the ages of the pregnant women in our cohort. However, another study showed that $89 \%$ of asymptomatic elderly people with COVID-19 living in nursing homes developed symptoms ${ }^{15}$. Turan et al. ${ }^{27}$ reported that approximately $3 \%$ of all mild diseases progress to severe or critical infections. The present study revealed that none of the asymptomatic patients became clinically severe.

Data from population-based studies and case series suggest that COVID-19 infection in pregnancy is mostly asymptomatic or mild, as in non-pregnant women 12-14,29-34. Similarly, in our study group, all symptomatic patients had clinically mild diseases (cough, fever, flu-like symptoms, minimal dyspnea, and $\mathrm{O}_{2}$ saturation of $>95 \%$ on room air) in the whole course.

The rate of preterm delivery was higher in asymptomatic women than those symptomatic (15\% vs. 7.3\%); however, this variation was statistically insignificant ( $p>0.05)$. Similarly, Berry et al. ${ }^{28}$ reported no statistical difference between the asymptomatic and symptomatic groups in terms of preterm delivery (11.9\% vs. 20\%). The rate of preterm birth (12.6\%) in hospital admissions of patients with SARS-CoV-2 was higher than the United States average (10\%) in $2018^{35}$. Delahoy et al..$^{23}$ revealed that preterm birth occurred nearly three times more often in symptomatic patients than in those asymptomatic $23.1 \%$ vs. $8 \%$ ). Additionally, London et al." found that the rate of preterm delivery was higher in symptomatic patients than in those asymptomatic ( $27.3 \%$ vs. $0 \%$ ).

To the best of our knowledge, only one research has compared symptomatic and asymptomatic groups in terms of LBW. Jenabi et al. ${ }^{26}$ reported that the rate of LBW was significantly higher in the symptomatic group. Contrarily, the present study revealed that the rates of LBW were higher in asymptomatic women than those symptomatic $(14.3 \%$ vs. $2.4 \%)$ but were not statistically significant.

The literature has been reported that the clinical course of COVID-19 infection is more severe and maternal and perinatal outcomes are more adverse in symptomatic pregnant women. Delahoy et al. ${ }^{23}$ reported that the disease progressed more seriously in symptomatic pregnant women with $16.2 \%$ being admitted to the ICU, 8.5\% needing mechanical ventilation, and $1 \%$ dying due to the disease. Additionally, among the asymptomatic patients, only 1 was admitted to the ICU, none required mechanical ventilation, and death was not observed. London et al." reported that pregnant women with COVID-19 symptoms on admission had a higher rate of severe illness than those asymptomatic. The present study revealed no statistical difference between the symptomatic and asymptomatic groups in terms of the clinical course of COVID-19 (ICU admission, need for intubation, and maternal death). No severe diseases were observed in any of the symptomatic pregnant women on admission and the whole course.

Additionally, ferritin levels were significantly higher in the symptomatic group but no significant differences 
between the groups in terms of CRP levels, lymphocyte counts, lymphopenia rates, platelet counts, D-dimer levels, and AST/ALT ratios. Some studies suggested that ferritin, CRP, and lymphocyte levels may be markers for COVID-19 severity ${ }^{36-38}$. However, similar to our study, other research suggests that lymphopenia rates, platelet counts, D-dimer levels, and AST/ALT ratios were similar between the symptomatic and asymptomatic groups ${ }^{39-42}$. The differences between these studies may be due to many factors such as genetics, comorbid diseases, and environmental factors. Additionally, our cohort was pregnant, and during pregnancy, many physiological changes occur in the respiratory, circulatory, and immunological systems.

The literature reported that approximately $14 \%$ of women who are admitted to the delivery room are asymptomatic with COVID-19, without difference in viral burden between asymptomatic and symptomatic patients, and with longer viral transmission period of asymptomatic. COVID-19 screening in all women hospitalization for delivery is essential for detecting asymptomatic patients and the protection of healthcare personnel ${ }^{11-13,15,21,22}$.

The mother-to-child intrauterine transmission of SARS-CoV-2 has not yet been demonstrated ${ }^{39}$. Recent studies reported that SARS-CoV-2 was not detected in throat swab, breast milk samples, cord blood, and amniotic fluid, and no evidence was found for motherto-infant transmission $32,43,44$. Studies of 38 Chinese patients infected with SARS-CoV-2 did not show mother-to-infant transmission ${ }^{43-46}$. Additionally, some studies demonstrated the vertical SARS-CoV-2 transmission ${ }^{47-50}$. This study tested 63 newborns for nasopharyngeal swabs in the first 24 hours of life. A positive PCR test was detected in only 1 newborn (from the asymptomatic group) out of the 63 newborns. More research is needed to fully uncover the mother-to-child intrauterine transmission of SARSCoV-2.

\section{Study Limitations}

This study has two main limitations. The sample size of this study was small. Further research with larger sample sizes is needed as not all confounders can be controlled. Additionally, COVID-19 prevalence in asymptomatic pregnant women admitted to the hospital was impossible as universal screening is not performed in the delivery room. However, in the literature, nearly $14 \%$ of patients were asymptomatic with COVID-19 when hospitalized for delivery ${ }^{11-13}$. This study is one of the few studies in the literature that investigated the postpartum outcomes of asymptomatic COVID-19 infection.

\section{CONCLUSIONS}

The rate of primary cesarean section was quite high in symptomatic pregnant women with COVID-19. Additionally, the total cesarean section rate was extremely high in both groups. Obstetricians can reduce the iatrogenic cesarean sections with obstetric interventions in the management of pregnant women with COVID-19. More adverse outcomes were expected in symptomatic patients, and similar maternal, perinatal, and neonatal outcomes were seen in both groups. Pregnant women who presented without symptoms tended to remain asymptomatic. Insufficient universal COVID-19 testing means that most cases go undetected. SARS-CoV-2 screening is required from all pregnant women who apply for delivery to protect the healthcare workers and identify asymptomatic patients.

\section{Ethics}

Ethics Committee Approval: The research was approved by the University of Health Sciences Turkey, Tepecik Training and Research Hospital Ethics Committee (decision no: 2021/03-39, date: 24.03.2021).

Informed Consent: Written consent for data use was routinely obtained from all participants at admission.

Peer-review: Externally and internally peerreviewed.

\section{Author Contributions}

Concept: T.V., B.B., Design: T.V., B.B., Data Collection and/or Processing: T.V., B.B., S.Y.K., O.O., N.Y., P.S., M.O., Analysis and/or Interpretation: T.V., B.B., S.Y.K., O.O., N.Y., P.S., M.O., Critical Revision: T.V., B.B., S.Y.K., O.O., N.Y., P.S., M.O., Writing: T.V., B.B., S.Y.K., O.O., N.Y., P.S., M.O.

Conflict of Interest: The authors have no conflict of interest to declare.

Financial Disclosure: The authors declared that this study has received no financial support.

\section{REFERENCES}

1. Barouki R, Kogevinas M, Audouze K, et al. The COVID-19 pandemic and global environmental change: Emerging research needs. Environ Int. 2021;146;106272.

2. Rampal L, Liew BS. Malaysia's third COVID-19 wave - a paradigm shift required. Med J Malaysia. 2021;76:1-4.

3. Graichen $\mathrm{H}$. What is the difference between the first and the second/third wave of Covid-19? - German perspective. J Orthop. 2021;24:Al-3.

4. Seong $\mathrm{H}$, Hyun HJ, Yun JG, et al. Comparison of the second and third waves of the COVID-19 pandemic in South Korea: Importance of early public health intervention. Int J Infect Dis. 2021;104:742-5. 
5. Karako K, Song P, Chen Y, Tang W, Kokudo N. Overview of the characteristics of and responses to the three waves of COVID-19 in Japan during 2020-2021. Biosci Trends. 2021;15:1-8.

6. Jin Y, Yang H, Ji W, et al. Virology, Epidemiology, Pathogenesis, and Control of COVID-19. Viruses. 2020;12:372.

7. Wang C, Horby PW, Hayden FG, Gao GF. A novel coronavirus outbreak of global health concern. Lancet. 2020;395:470-3.

8. Li N, Han L, Peng M, et al. Maternal and Neonatal Outcomes of Pregnant Women With Coronavirus Disease 2019 (COVID-19) Pneumonia: A Case-Control Study. Clin Infect Dis. 2020;71:203541.

9. Jacob CM, Briana DD, Di Renzo GC, et al. Building resilient societies after COVID-19: the case for investing in maternal, neonatal, and child health. Lancet Public Health. 2020;5:e624-7.

10. Capanna F, Haydar A, McCarey C. Preparing an obstetric unit in the heart of the epidemic strike of COVID-19: quick reorganization tips. J Matern Fetal Neonatal Med. 2020;1-7.

11. London L, McLaren R, Atallah F, et al. The Relationship between Status at Presentation and Outcomes among Pregnant Women with COVID-19, Am J Perinatol. 2020;37:991-4.

12. Sutton D, Fuchs K, D'Alton M, Goffman D. Universal Screening for SARS-CoV-2 in Women Admitted for Delivery. N Engl J Med. 2020;382:2163-4.

13. Crovetto F, Crispi F, Llurba E, Figueras F, Gómez-Roig MD, Gratacós E. Seroprevalence and presentation of SARS-CoV-2 in pregnancy Lancet. 2020;396:530-1.

14. Breslin N, Baptiste C, Gyamfi-Bannerman C, et al. Coronavirus disease 2019 infection among asymptomatic and symptomatic pregnant women: two weeks of confirmed presentations to an affiliated pair of New York City hospitals. Am J Obstet Gynecol MFM. 2020;2:100118.

15. Arons MM, Hatfield KM, Reddy SC, et al. Presymptomatic SARSCoV-2 Infections and Transmission in a Skilled Nursing Facility. N Engl J Med. 2020;382:2081-90.

16. Corman VM, Rabenau HF, Adams $\mathrm{O}$, et al. SARS-CoV-2 asymptomatic and symptomatic patients and risk for transfusion transmission. Transfusion. 2020;60:1119-22.

17. Gautret P, Lagier JC, Parola P, et al. Hydroxychloroquine and azithromycin as a treatment of COVID-19: results of an openlabel non-randomized clinical trial, Int J Antimicrob Agents. 2020;56:105949.

18. Kam KQ Yung CF, Cui L, et al. A Well Infant With Coronavirus Disease 2019 With High Viral Load. Clin Infect Dis. 2020;71:847-9.

19. Lavezzo E, Franchin E, Ciavarella C, et al. Suppression of a SARS-CoV-2 outbreak in the Italian municipality of Vo'. Nature. 2020;584:425-9.

20. Le TQM, Takemura T, Moi ML, et al. Severe Acute Respiratory Syndrome Coronavirus 2 Shedding by Travelers, Vietnam, 2020. Emerg Infect Dis. 2020;26:1624-6.

21. Wan R, Mao ZQ He LY, Hu YC, Chen W. Evidence from two cases of asymptomatic infection with SARS-CoV-2: Are 14 days of isolation sufficient? Int J Infect Dis. 2020;95:174-5.

22. Long QX, Tang XJ, Shi QL, et al. Clinical and immunological assessment of asymptomatic SARS-CoV-2 infections. Nat Med. 2020;26:1200-4.

23. Delahoy MJ, Whitaker M, O'Halloran A, et al. Characteristics and Maternal and Birth Outcomes of Hospitalized Pregnant
Women with Laboratory-Confirmed COVID-19 - COVID-NET, 13 States, March 1-August 22, 2020. MMWR Morb Mortal Wkly Rep. 2020;69:1347-54.

24. Gestational Hypertension and Preeclampsia: ACOG Practice Bulletin, Number 222. Obstet Gynecol. 2020;135:e237-60.

25. SPSS Statistics - Overview, (2021). Available from: https://www. ibm.com/products/spss-statistics Last accessed: January 9, 2022.

26. Jenabi E, Bashirian S, Khazaei S, et al. Pregnancy outcomes among symptomatic and asymptomatic women infected with COVID-19 in the west of Iran: a case-control study. J Matern Fetal Neonatal Med. 2020;1-3.

27. Turan O, Hakim A, Dashraath P, et al. Clinical characteristics, prognostic factors, and maternal and neonatal outcomes of SARS-CoV-2 infection among hospitalized pregnant women: A systematic review. Int J Gynaecol Obstet. 2020;151:7-16.

28. Berry M, Wang A, Clark SM, et al. Clinical Stratification of Pregnant COVID-19 Patients based on Severity: A Single Academic Center Experience. Am J Perinatol. 2021;38:515-22.

29. Fassett MJ, Lurvey LD, Yasumura L, et al. Universal SARS-Cov-2 Screening in Women Admitted for Delivery in a Large Managed Care Organization. Am J Perinatol. 2020;37:1110-4.

30. Allotey J, Stallings $E$, Bonet $M$, et al. Clinical manifestations, risk factors, and maternal and perinatal outcomes of coronavirus disease 2019 in pregnancy: living systematic review and metaanalysis. BMJ. 2020;370:m3320.

31. Hirshberg A, Kern-Goldberger AR, Levine LD, et al. Care of critically ill pregnant patients with coronavirus disease 2019: a case series. Am J Obstet Gynecol. 2020;223:286-90.

32. Yan J, Guo J, Fan C, et al. Coronavirus disease 2019 in pregnant women: a report based on 116 cases. Am J Obstet Gynecol. 2020;223:111.el-111.el4.

33. Ferrazzi E, Frigerio L, Savasi V, et al. Vaginal delivery in SARS - CoV - 2 - infected pregnant women in Northern Italy: a retrospective analysis. BJOG. 2020;127:1116-21.

34. Salvatori G, De Rose DU, Concato C, et al. Managing COVID-19Positive Maternal-Infant Dyads: An Italian Experience. Breastfeed Med. 2020;15:347-8.

35. Martin JA, Hamilton BE, Osterman MJK, Driscoll AK. Births: Final Data for 2018. Natl Vital Stat Rep. 2019;68:1-47.

36. Lin Z, Long F, Yang Y, Chen X, Xu L, Yang M. Serum ferritin as an independent risk factor for severity in COVID-19 patients. J Infect. 2020;81:647-79.

37. Wang L. C-reactive protein levels in the early stage of COVID-19. Med Mal Infect. 2020;50:332-4.

38. Ma $\mathrm{Y}, \mathrm{Xu} \mathrm{QN}$, Wang $\mathrm{FL}$, et al. Characteristics of asymptomatic patients with SARS-CoV-2 infection in Jinan, China. Microbes Infect. 2020;22:212-7.

39. AUjishi JM, Alhajjaj AH, Alkhabbaz FL, et al. Clinical characteristics of asymptomatic and symptomatic COVID-19 patients in the Eastern Province of Saudi Arabia. J Infect Public Health. 2021;14:611.

40. Samrah SM, Al-Mistarehi AHW, Ibnian AM, etal.COVID-19 outbreak in Jordan: Epidemiological features, clinical characteristics, and laboratory findings. Ann Med Surg (Lond). 2020;57:103-8.

41. Yoon S, Li H, Lee KH, et al. Clinical Characteristics of Asymptomatic and Symptomatic Pediatric Coronavirus Disease 2019 (COVID-19): A Systematic Review. Medicina (Kaunas). 2020;56:474. 
42. Li Y, Shi J, Xia J, et al. Asymptomatic and Symptomatic Patients With Non-severe Coronavirus Disease (COVID-19) Have Similar Clinical Features and Virological Courses: A Retrospective Single Center Study. Front in Microbiol. 2020;11:1570.

43. Chen H, Guo J, Wang C, et al. Clinical characteristics and intrauterine vertical transmission potential of COVID-19 infection in nine pregnant women: a retrospective review of medical records. Lancet. 2020;395:809-15.

44. Zhu $\mathrm{H}$, Wang L, Fang $\mathrm{C}$, et al. Clinical analysis of 10 neonates born to mothers with 2019-nCoV pneumonia. Transl Pediatr. 2020;9:5160.

45. Liu W, Wang $Q$ Zhang $Q$ et al. Coronavirus Disease 2019 (COVID-19) During Pregnancy: A Case Series. Available from: https://www.preprints.org/manuscript/202002.0373/vl Last accessed: August 30, 2021
46. Wang X, Zhou Z, Zhang J, Zhu F, Tang Y, Shen X. A Case of 2019 Novel Coronavirus in a Pregnant Woman With Preterm Delivery. Clin Infect Dis. 2020;71:844-6.

47. Alzamora MC, Paredes T, Caceres D, Webb CM, Valdez LM, La Rosa M. Severe COVID-19 during Pregnancy and Possible Vertical Transmission. Am J Perinatol. 2020;37:861-5.

48. Blumberg DA, Underwood MA, Hedriana HL, Lakshminrusimha S. Vertical Transmission of SARS-CoV-2: What is the Optimal Definition? Am J Perinatol. 2020;37:769-72.

49. Zeng L, Xia S, Yuan W, et al. Neonatal Early-Onset Infection With SARS-CoV-2 in 33 Neonates Born to Mothers With COVID-19 in Wuhan, China. JAMA Pediatr. 2020;174:722-5.

50. Fenizia C, Biasin M, Cetin I, et al. Analysis of SARS-CoV-2 vertical transmission during pregnancy. Nat Commun. 2020;11:5128. 